\title{
Bimbingan Teknis Pertanian Organik sebagai Penerapan Teknologi Budidaya Ramah Lingkungan kepada Perkumpulan Kelompok Tani Gapsera Sejahtera Mandiri
}

\author{
Organic Agriculture Technical Guidance as the Application of Environmentally Friendly \\ Cultivation Technology to the Gapsera Sejahtera Mandiri Farmer Group Association
}

\section{Dulbari ${ }^{*}$ \\ Yuriansyah ${ }^{1}$ \\ Hery Sutrisno ${ }^{1}$ \\ Arief Maksum ${ }^{2}$ \\ Destieka Ahyuni ${ }^{1}$ \\ Lina Budiarti 1 \\ Hidayat Saputra ${ }^{1}$ \\ Miranda Ferwita Sari ${ }^{3}$ \\ ${ }^{1}$ Department of Food Crop Production, Politeknik Negeri Lampung, Bandar Lampung, Lampung, Indonesia \\ 2Department of Economics and Business, Politeknik Negeri Lampung, Bandar Lampung, Lampung, Indonesia \\ 3Department of Seed Technology, Politeknik Negeri Lampung, Bandar Lampung, Lampung, Indonesia}

email: dulbari23@yahoo.co.id

Kata Kunci

Masyarakat

Pengabdian

Pertanian

Keywords:

Public

Devotion

Agriculture

Received: October 2020

Accepted: March 2021

Published: April 2021

\begin{abstract}
Abstrak
Pertanian organik merupakan salah satu sistem budidaya yang menerapkan konsep pertanian berkelanjutan. Sistem budidaya pertanian organik mengandalkan bahan-bahan alami tanpa menggunakan bahan kimia sintetis. Budidaya organik merupakan kegiatan bercocok tanam yang ramah atau akrab dengan lingkungan dengan terus berusaha untuk meminimalkan dampak negatif bagi lingkungan sekitar. Tujuan kegiatan ini yaitu memberikan pengetahuan dan keterampilan tentang konsep pertanian berkelanjutan yang dilaksanakan melalui penerapan sistem pertanian organik di Polinela Organic Farm. Kegiatan bimbingan teknis dilaksanakan di kebun Polinela Organic Farm Politeknik Negeri Lampung. Hari Selasa 10 Maret 2020. Peserta merupakan Gabungan Kelompok Tani Sejahtera Mandiri Desa Rejo Asri Kecamatan Seputuh Raman Kabupaten Lampung Tengah. Penerapan aspek pertanian ramah lingkungan tercermin dalam pengelolaan konsep pertanian organik yang dilaksanakan oleh Polinela Organic Farm. Konsep pembangunan pertanian ramah lingkungan dilaksanakan dengan memperhatikan berbagai aspek yaitu penggunaan pupuk anorganik bersifat suplementatif dengan efisiensi tinggi, penerapan pengendalian hama dan penyakit dengan memperhatikan keseimbangan ekologis alamiah, penerapan pengelolaan tanaman secara terpadu, penerapan sistem usaha tani bersih dan sehat, pemeliharaan dan pemantapan kesuburan fisik, kimiawi, dan hayati secara alamiah dan pemanfaatan teknologi efektif berdasar kearifan lokal. Kata kunci : masyarakat, pengabdian, pertanian.
\end{abstract}

\begin{abstract}
Organic agriculture was a cultivation system that applies the concept of sustainable agriculture. Organic farming systems depend on natural ingredients without using synthetic chemicals. Organic cultivation was environmentally friendly by farming activities by continuing to minimize negative impacts on the surrounding environment. This activity aims to provide knowledge and skills on the concept of sustainable agriculture, which is carried out through the application of an organic farming system at Polinela Organic Farm. Technical guidance activities are carried out at the Polinela Organic Farm, Lampung State Polytechnic, on Tuesday, March 10, 2020. Participants were the Association of 'Sejahtera Mandiri' Farmers Groups Rejo Asri Village, Seputuh Raman, Central Lampung. The application of environmental friendly in agricultural aspects was reflected in the management of the concept of organic agriculture carried out by Polinela Organic Farm. The concept of environmental friendly in agricultural development was implemented by taking into various aspects, such as the use of inorganic fertilizers with high efficiency, the application of pest and disease control by notice the natural ecological balance, the application of integrated crop management, the application of a clean and healthy farming system, the maintenance and strengthening of physical fertility, chemical, and biological in nature and the use of effective technology based on local wisdom.
\end{abstract}




\section{PENDAHULUAN}

Tantangan pembangunan pertanian dihadapkan pada saat ini adalah adanya perubahan iklim yang dapat memicu kerawanan pangan, konversi lahan pertanian menjadi non pertanian, pertumbuhan penduduk yang terus meningkat akan meningkatkan kebutuhan bahan pangan, eksploitasi alam secara berlebihan mengakibatkan degradasi sumber daya lahan pertanian sehingga dapat menurunkan kualitas tanah, lingkungan, dan produk pertanian (Suryana, 2014; Purwaningsih, 2008). Undang- Undang No 18 tahun 2012 tentang Pangan telah mengamanatkan bahwa selain ketahanan dan kemandirian pangan, serta keamanan pangan perlu diperhatikan. Meningkatnya produktivitas tanaman pangan harus diimbangi dengan peningkatan kualitas tanah dan produk pertanian (Wihardjaka, 2018; Winarso, 2013).

Pertanian organik merupakan salah satu sistem budidaya yang menerapkan konsep pertanian berkelanjutan. Sistem budidaya pertanian organik mengandalkan bahan-bahan alami tanpa menggunakan bahan kimia sintetis. Budidaya organik merupakan kegiatan bercocok tanam yang ramah atau akrab dengan lingkungan dengan terus berusaha untuk meminimalkan dampak negatif bagi lingkungan sekitar (Rachma \& Umam, 2020;:Mayrowani, 2012).

Ciri utama pertanian organik yaitu mengoptimalkan penggunaan varietas lokal, penggunaan pupuk dan pestisida organik, serta tidak merusak lingkungan. Konsep pertanian organik adalah konsep cara menanam tanaman dengan pendekatan alami yang menekankan terhadap perlindungan lingkungan dan pelestarian sumberdaya air dan tanah yang berkelanjutan (Rivai \& Anugrah, 2011). Pertanian organik tidak menggunakan pupuk sintetis yang berasal dari bahan baku tidak terbarukan, pestisida, meminimalkan penggunaan bahan bakar minyak dan makanan dari hasil modifikasi genetika (Efendi, 2016). Adapun tujuan dari kegiatan pengabdian ini adalah memberikan pengetahuan dan keterampilan tentang konsep pertanian berkelanjutan yang dilaksanakan melalui penerapan sistem pertanian organik di Polinela Organic Farm.

\section{METODOLOGI}

Kegiatan bimbingan teknis dilaksanakan di kebun Polinela Organic Farm Politeknik Negeri Lampung. Hari Selasa 10 Maret 2020. Peserta dari kegiatan pengabdian ini adalah Gabungan Kelompok Tani Sejahtera Mandiri Desa Rejo Asri Kecamatan Seputuh Raman Kabupaten Lampung Tengah yang berjumlah 60 orang. Terdiri dari Laki-laki dan perempuan, tua dan muda, seperti ditunjukkan pada Gambar 1 dan 2.

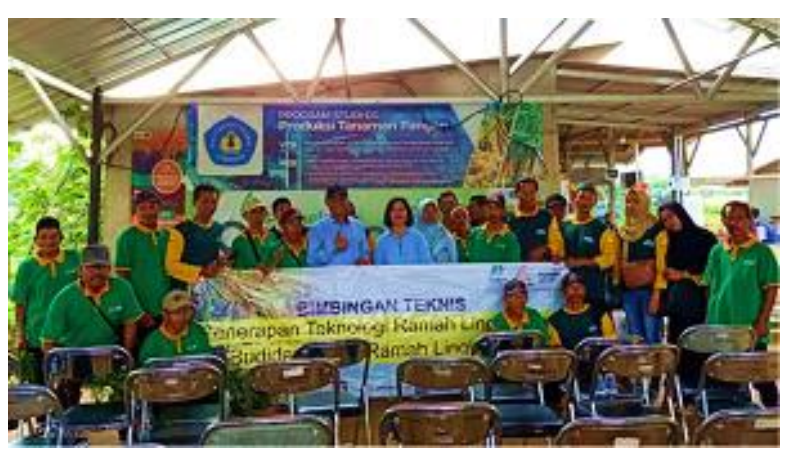

Gambar 1. Kunjungan Gabungan Kelompok Tani Sejahtera Mandiri ke Polinela Organic farm

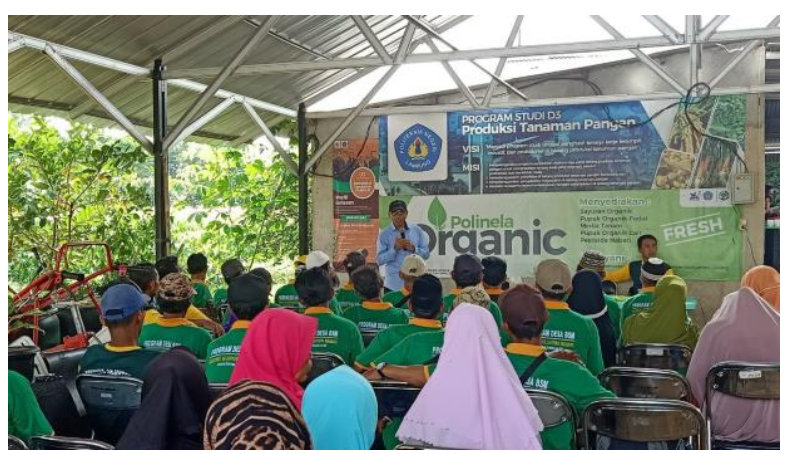

Gambar 2. Anggota gabungan Kelompok Tani Sejahtera Mandiri sedang mendengarkan penjelasan tentang konsep pertanian berkelanjutan

Kegiatan dilaksanakan dalam bentuk ceramah, diskusi/tanya jawab, Field Tour, dan demontrasi/praktik langsung. Materi ceramah berisi tentang konsep 
pertanian berkelanjutan yang diterapkan memalui teknik budidaya pertanian organik yang disampaikan oleh pengelola Polinela Organic Farm. Kegiatan Field Tour dilakukan dengan mengelilingi kebun Polinela Organic Farm didampingi oleh dosen dan PLP Program Studi Produksi Tanaman Pangan Politeknik Negeri Lampung. Dalam kegiatan keliling kebun juga dijelaskan sejarah berdirinya Polinela Organic Farm, kegiatan usaha yang dilakukan, dan tujuan dibentuknya Teaching Farm Pertanian Organik. Kegiatan demonstrasi/praktik yang dilakukan adalah pembuatan pupuk organik dan pestisida nabati yang didampingi oleh dosen dan mahasiwa Program Studi Produksi Tanaman Pangan Politeknik Negeri Lampung.

\section{HASIL DAN PEMBAHASAN}

\section{Prinsip Pertanian Organik dan Pertanian Berkelanjutan}

Prinsip yang harus diterapkan dalam sistem pertanian organik antara lain:

1. Prinsip Kesehatan.

Pertanian organik harus melestarikan dan meningkatkan kesehatan tanah, tanaman, hewan, manusia dan bumi sebagai satu kesatuan dan tak terpisahkan. Prinsip ini menunjukkan bahwa kesehatan tiap individu dan komunitas tak dapat dipisahkan dari kesehatan ekosistem, tanah yang sehat akan menghasilkan tanaman sehat yang dapat mendukung kesehatan hewan dan manusia. Kesehatan merupakan bagian yang tak terpisahkan dari sistem kehidupan. Hal ini tidak saja sekedar bebas dari penyakit, tetapi juga dengan memelihara kesejahteraan fisik, mental, sosial dan ekologi. Pertanian organik baik dalam produksi, pengolahan, distribusi dan konsumsi bertujuan untuk melestarikan dan meningkatkan kesehatan ekosistem dan organisme, dari yang terkecil yang berada di dalam tanah hingga manusia.
2. Prinsip Ekologi.

Pertanian organik harus didasarkan pada sistem dan siklus ekologi kehidupan. Bekerja, meniru dan berusaha memelihara sistem dan siklus ekologi kehidupan. Prinsip ekologi meletakkan pertanian organik dalam sistem ekologi kehidupan. Prinsip ini menyatakan bahwa produksi didasarkan pada proses dan daur ulang ekologis. Pengelolaan organik harus disesuaikan dengan kondisi, ekologi, budaya dan skala lokal. Bahan-bahan asupan sebaiknya dikurangi dengan cara dipakai kembali, didaur ulang dan dengan pengelolaan bahan-bahan dan energi secara efisien guna memelihara, meningkatkan kualitas dan melindungi sumber daya alam. Pertanian organik dapat mencapai keseimbangan ekologis melalui pola sistem pertanian, membangun habitat, pemeliharaan keragaman genetika dan pertanian.

3. Prinsip Keadilan.

Pertanian organik harus membangun hubungan yang mampu menjamin keadilan terkait dengan lingkungan dan kesempatan hidup bersama. Keadilan dicirikan dengan kesetaraan, saling menghormati, berkeadilan dan pengelolaan dunia secara bersama, baik antar manusia dan dalam hubungannya dengan makhluk hidup lain. Prinsip ini menekankan bahwa mereka yang terlibat dalam pertanian organik harus membangun hubungan yang manusiawi untuk memastikan adanya keadilan bagi semua pihak di segala tingkatan: seperti petani, pekerja, pemroses, penyalur, pedagang dan konsumen. Pertanian organik harus memberikan kualitas hidup yang baik bagi setiap orang yang terlibat, menyumbang bagi kedaulatan pangan dan pengurangan kemiskinan. Pertanian organik bertujuan untuk menghasilkan kecukupan dan ketersediaan pangan dengan kualitas yang baik. 


\section{Prinsip Perlindungan.}

Pertanian organik harus dikelola secara hati-hati dan bertanggungjawab untuk melindungi kesehatan dan kesejahteraan generasi sekarang dan mendatang serta lingkungan hidup. Pertanian organik merupakan suatu sistem yang hidup dan dinamis yang menjawab tuntutan dan kondisi yang bersifat internal maupun eksternal. Para pelaku pertanian organik didorong meningkatkan efisiensi dan produktivitas, tetapi tidak boleh membahayakan kesehatan dan kesejahteraannya. Prinsip ini menyatakan bahwa pencegahan dan tanggung jawab merupakan hal mendasar dalam pengelolaan, pengembangan dan pemilihan teknologi di pertanian organik. Ilmu pengetahuan diperlukan untuk menjamin bahwa pertanian organik bersifat menyehatkan, aman dan ramah lingkungan. Tetapi pengetahuan ilmiah saja tidaklah cukup. Seiring waktu, pengalaman praktek yang dipadukan dengan kebijakan dan kearifan tradisional menjadi solusi tepat. Pertanian organik harus mampu mencegah terjadinya resiko merugikan dengan menerapkan teknologi tepat guna dan menolak teknologi yang tak dapat diramalkan akibatnya, seperti rekayasa genetika (genetic engineering) (International Federation of Organic Agriculture Movements, 2020).

\section{Penerapan Teknologi Pertanian Organik di Polinela}

\section{Organic Farm}

\section{Pengolahan Tanah dan Pengelolaan Air}

Pengolahan tanah tujuan untuk menyediakan media tumbuh agar sesuai dengan apa yang dibutuhkan tanaman. Tanaman akan tumbuh dengan baik pada media tanah yang subur dan gembur, cukup tersedia aerasi serta mempunyai sistem drainase yang baik. Pengolahan tanah pada sistem pertanian organik khususnya pada komoditas sayuran dilakukan secara manual menggunakan cangkul. Metode pengolahan tanah yang dilakukan adalah minimum tillage, untuk menghindari kerusakan dan pemadatan tanah secara berlebihan. Dengan pengolahan tanah secara manual, sisa-sisa tanaman dan rumput dapat sekaligus ditimbun sebagai cadangan dan tambahan bahan organik. Sebelum penanaman dilakukan pembuatan bedengan dengan ukuran lebar $120 \mathrm{~cm}$, tinggi 20-30 cm, panjang bedengan menyesuaikan ukuran lahan. Jarak antar bedeng sekitar $30 \mathrm{~cm}$. Sebagai pupuk dasar diberikan pupuk organik berupa kompos/kotoran hewan yang sudah difermentasikan dengan kebutuhan $1 \mathrm{~kg} / \mathrm{m}^{2}$. Pemberian kapur pertanian diperlukan bila $\mathrm{pH}$ tanah asam $(<6)$ sesuai dengan kebutuhan.

Pengelolaan air untuk sistem pertanian organik memerlukan pengaturan. Bila kebutuahan air tanaman disuplai dari irigasi umum, sebelum air masuk ke lahan harus terlebih dulu dikopndisikan yaitu dengan membuat bak sejenis kolam dengan tujuan untuk menjaga kualitas air yang dibutuhkan tanaman serta mencegah terjadinya pencemaran bahan (pupuk maupun pestisida). Kolam pengkondisian dibuat sebanyak 3 buah dengan penataan di sekitar bak penampungan pertama ditanami pohon pisang wuluh/ungu atau tanaman yang dapat bersifat sebagai penyerap dan menetralisir bahan residu berbahaya. Pada bak penampungan pertama disebar tanaman enceng gondok atau azolla yang berfungsi untuk mengurangi kandungan bahan kimia yang ada pada air irigasi. Bak penampungan dipasang dua pembatas untuk membagi menjadi 3 ruangan. Ruangan pertama diisi dengan ijuk, ruang kedua diisi batu krakal/kali/batu gamping, dan ruang ketiga berisi arang. Bak penampungan ke tiga kembali diberikan tanaman enceng gondok atau azolla sebagai tanaman indikator. Kalau enceng gondok pada bak kolam penampungan ke tiga tumbuh tidak tumbuh subur 
(daunnya kecil-kecil dan berwarna kekuningan), tidak lagi ditemukan telur keong, berarti air sudah dalam kondisi baik (tidak tercemar dan dapat diaplikasikan ke lahan budidaya secara organik.

\section{Penanaman dan Rotasi Tanaman}

Penanaman pada sistem pertanian organik dilakukan dengan menggunakan pola rotasi tanaman. Rotasi tanaman adalah praktik penanaman berbagai jenis tanaman secara bergiliran di satu lahan. Rotasi tanaman sangat memberikan manfaat bagi kesehatan lahan pertanian. Elemen penting dari sistem rotasi tanaman adalah pengembalian nutrisi terutama nitrogen melalui tanaman kacang-kacangan (legume) setelah penanaman tanaman lain. Rotasi tanaman juga dapat mencegah terakumulasinya patogen dan hama yang menyerang satu jenis tanaman. Rotasi tanaman dapat memperbaiki sifat fisik, kimia dan biologi tanah. Pola pergantian antara tanaman berakar dalam dengan tanaman berakar dangkal juga dapat menjaga kesubutan tanah. Rotasi tanaman dapat dibedakan menjadi menurut selang waktu yang akan dilakukan. Untuk pendek rotasi yang dapat menggunakan pilihan tanaman legume dan nonlegume. Untuk rotasi sedang pilihan tanamannya adalah legume - sayuran daun (leaf) - sayuran buah (fruit) kembali ke legume. Rotasi panjang menggunakan pilihan legume - leaf - fruit - umbi (root) dan kembali lagi ke legume.

\section{Aplikasi Pupuk Organik}

Aplikasi pupuk organik pada sistem pertanian organik diperlukan untuk mencukupi kebutuhan hara tanaman. Penambahan unsur hara melalui pemupukan dapat menggantikan unsur hara yang hilang akibat erosi dan tercuci. Pupuk organik adalah pupuk kimia hasil fermentasi bahan bahan alam. Pemberian pupuk organik sesuai kebutuhan tanaman merupakan kunci keberhasilan dalam budidaya pertanian organik. Pupuk organik mengandung unsur hara mikro, makro, asam amino, dan hormon yang dibutuhkan tanaman. Selain itu di dalam pupuk organik juga terdapat mikroorganisme yang akan memperbaiki tingkat kesehatan dan kesuburan tanah sehingga menunjang pertumbuhan dan perkembangan tanaman secara optimal.

Pupuk organik mengandung unsur hara makro dan mikro lengkap, tetapi jumlahnya sedikit. Aplikasi pupuk organik pada lahan pertanian organik dapat memperbaiki sifat fisik, kimia, dan boilogi tanah, sehingga dalam jangkan panjang tanah akan menjadi subur dan sehat Pupuk organik mempunyai kemampuan mengikat air (water holding capacity) yang tinggi. Beberapa tanaman yang dipupuk dengan pupuk organik lebih tahan terhadap serangan penyakit. Meningkatkan aktivitas mikroorganisme tanah yang menguntungkan. Memiliki residual effect yang positif, sehingga tanaman yang ditanam pada musim berikutnya tetap bagus pertumbuhan dan produktivitasnya. Pupuk organik dapat dibuat dengan memanfaatkan limbah pertanian yang ada seperti kotoran hewan dan sisa-sisa tanaman yang banyak tersedia di lahan pertanian. Untuk membuat pupuk organik berkualitas sebanyak 1 ton diperlukan bahanbahan berupa kotoran sapi sekitar 1 ton, hijauan yang mudah busuk, daun-daun kering secukupnya, urine sapi $20 \mathrm{~L}$, air kelapa $20 \mathrm{~L}$, tetes tebu 1,5 L, dekomposer 2 L, dan kapur $10 \mathrm{~kg}$.

Cara pembuatannya adalah kotoran sapi diratakan dengan ketinggian sekitar 0,5 meter, hijauan dan daundaun kering dicacah dan disebar secara merata kemudian taburkan kapur. Campuran tetes tebu, urine sapi, air kelapa, dekomposer, dan air diaduk dalam ember besar, kemudian disiram secara merata. Kotoran sapi sisanya ditaburkan lagi secara merata. Tumpukan kotoran sapi dan daun-daunan dapat dibuat berlapis. Setiap lapiran dilakukan penyiraman menggunakan 
campuran tetes tebu, urine sapi, air kelapa, dan dekomposer, kemudian dilakukan penutupan menggunakan plastik atau terpal agar proses fermentasi berjalan secara sempurna. Setelah 2 minggu dibalik dan dicek tingkat kekeringannnya, apabila terlalu panas dan terlalu kering bisa ditambahkan lagi air, kemudian ditutup kembali dan dibiarkan selama 2 minggu. Tandatanda pupuk organik yang sudah matang apabila dipegang tidak menempel ditangan, tidak bau kotoran, basah tapi tidak lengket, dan berwarna coklat kehitaman.

\section{Aplikasi Pestisida Nabati}

Penggunaan pestisida nabati pada sistem pertanian organik untuk menekan organisme pengganggu tanaman merupakan alternatif yang perlu dipersiapkan. Tujuan penggunaan pestisida nabati selain untuk mengendalikan potensi serangan organisme pengganggu tanaman juga untuk meminimalkan penggunaan pestisida sintetis, sehingga kerusakan lingkungan dapat dicegah. Aplikasi pestisida lebih ramah terhadap lingkungan, mudah terurai, tidak meningkgalkan residu, bahannya mudah didapatkan, dan lebih murah. Namun pestisida nabati juga mempunyai beberapa kelemahan antara lain tidak tahan lama untuk disimpan, memerlukan waktu untuk membunuh hama sasaram, dan harus dibuat setiap kali aplikasi. Untuk mengetahui efektivitas pestisida nabati dapat dilakukan dengan eksperimen dan pengalaman lapangan. Jika dosis yang digunakan kurang memberikan dampak, aplikasi berikutnya dosis dapat ditingkatkan.

Faktor utama yang harus diperhatikan dalam aplikasi pestisida nabati adalah sesuaikan dengan karakteristik pertumbuhan tanaman, karakteristik bahan yang akan digunakan, dan karakteristik hama sasaran. Dengan mengetahui informasi tentang karakter hama dapat mencari kelemahan dari hama tersebut. Pestisida nabati dapat dibuat dari berbagai jenis tumbuhan yang tidak dapat dijelaskan secara khusus atau distandarisasi karena memang sifatnya yang sangat beragam di alam. Satu ramuan pestisida nabati yang berhasil baik atau bersifat efektif di suatu tempat belum tentu mempunyai sifat serupa di tempat lainnya, karena kandungan bahan aktifnya bersifat spesifik lokasi. Tumbuhan yang sama, yang hidup di lingkungan yang berbeda akan mempunyai kandungan bahan aktif yang berbeda. Oleh sebab itu, dosis atau konsentrasi bahan aktif yang digunakan akan berbeda pula. Olah karena itu ramuan pestisida nabati akan tergantung kepada hasil pengujian di lokasi setempat dan kemungkin tidak akan berlaku di tempat lain (tidak berlaku umum).

Pembuatan pestisida nabati secara sederhana maupun secara laboratorium. Petani dapat melakukan sendiri praktik pembuatan pestisida nabati secara sederhana dengan cara ekstraksi (Tuhuteru et al., 2019). Pembuatan pestisida nabati dapat dilakukan beberapa teknik berikut:

1. Perebusan, pembakaran, penumbukan, atau pengepresan untuk menghasilkan produk berupa tepung, abu, atau pasta.

2. Perendaman untuk menghasilkan ekstrak.

3. Cara ekstraksi menggunakan bahan pelarut kimia. Beberapa jenis tumbuhan yang dapat diperguanakan sebagai bahan pestisida nabati antara lain Piretrum (Chrysantemum cinerarinefolum Trev.), Famili Compositae, Aglaia (Aglaia odorata), Famili Meliaceae, Babadotan (Ageratum conyzoides L.), Famili Asteraceae, Bengkuang (Phachyrrhyzus erosus Urban), Famili Leguminosae, Bitung (Barringtonia acutangula), Famili Lecythidaceae, Jeringau (Acorus calamus), Famili Araceae, Saga (Abrus precatorius), Famili Leguminosae, Serai (Andropogon nardus), Famili Graminae, Sirsak (Annona muricata), Famili Annonaceae, Srikaya (Annona squamosa), Famili Annonaceae. 
Pestisida nabati dapat dibuat secara sederhana dengan cara daun mimba, lengkuas dan serai ditumbuk atau dihaluskan. Seluruh bahan diaduk dalam $20 \mathrm{~L}$ air lalu direndam selama 24 jam, setelah itu larutan disaring. Larutan hasil penyaringan dapat diencerkan ketika akan digunakan. 1 L larutan dilarutkan dengan $30 \mathrm{~L}$ air, dimana larutan ini dapat digunakan untuk luasan lahan 1 hektar. Salah satu dokumentasi kegiatan disajikan pada Gambar3.

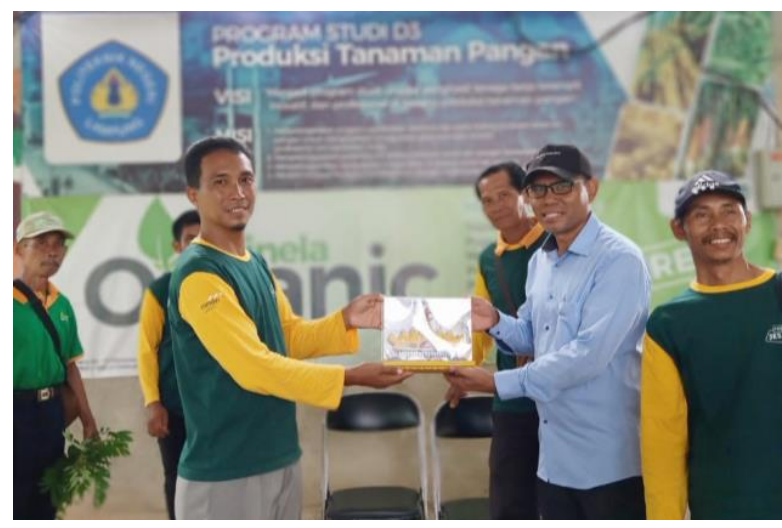

Gambar 3. Penyerahan secara simbolis kenang-kenangan Kepada perwakilan Kelompok Tani Sejahtera Mandiri

\section{KESIMPULAN}

Konsep pembangunan pertanian ramah lingkungan dilaksanakan dengan memperhatikan berbagai aspek antara lain penggunaan pupuk anorganik bersifat suplementatif dengan efisiensi tinggi untuk mencapai target hasil optimal, penerapan pengendalian hama dan penyakit dengan memperhatikan keseimbangan ekologis alamiah, penerapan pengelolaan tanaman secara terpadu, penerapan sistem usaha tani bersih dan sehat, pemeliharaan dan pemantapan kesuburan fisik, kimiawi, dan hayati secara alamiah, pemanfaatan teknologi efektif berdasar kearifan lokal, serta penerapan aspek pertanian ramah lingkungan tercermin dalam pengelolaan konsep pertanian organic yang dilaksanakan oleh Polinela Organic Farm.

\section{UCAPAN TERIMA KASIH}

Ucapan Terima kasih disampaikan Kepada Kemenristek Dikti melalui DRPM yang telah memberikan Dukungan pendanaan kegiatan ini melalui skema PPUPIK Tahun anggaran 2020.

\section{REFERENSI}

Efendi, E. 2016. Implementasi Sistem Pertanian Berkelanjutan Dalam Mendukung Produksi Pertanian. Majalah Ilmiah Warta Dharmawangsa. 47:1-20. https://doi.org/10.46576/wdw.v0i47.231

International Federation of Organic Agriculture Movements. 2020. The Four Pronciples of Organic Agriculture. https://www.ifoam.bio/whyorganic/shaping-agriculture/four-principlesorganic

Mayrowani, H. 2012. Pengembangan Pertanian Organik Di Indonesia. Forum Penelitian Agro Ekonomi. 30(2):91-108. http://dx.doi.org/10.21082/fae.v30n2.2012.9 $1-108$

Purwaningsih, Y. 2008. Ketahanan Pangan: Situasi, Permasalahan, Kebijakan, Dan Pemberdayaan Masyarakat. Jurnal Ekonomi Pembangunan: Kajian Masalah Ekonomi dan Pembangunan. 9(1):1-27. https://doi.org/10.23917/jep.v9i1.1028

Rachma, N., Umam, A.S. 2020. Pertanian Organik Sebagai Solusi Pertanian Berkelanjutan Di Era New Normal. Jurnal Pembelajaran Pemberdayaan Masyarakat (JP2M). 1(4):328-338. http://dx.doi.org/10.33474/jp2m.v1i4.8716

Rivai, R.S., Anugrah, I.S. 2011. Konsep Dan Implementasi Pembangunan Pertanian Berkelanjutan Di Indonesia. Forum Penelitian Agro Ekonomi. 29(1):13-25.

http://dx.doi.org/10.21082/fae.v29n1.2011.1 3-25

Suryana, A. 2014. Menuju Ketahanan Pangan Indonesia Berkelanjutan 2025: Tantangan Dan Penanganannya. Forum Penelitian Agro Ekonomi. 32(2):123-135. http://dx.doi.org/10.21082/fae.v32n2.2014.1 23-135 
Tuhuteru, S., Mahanani, A.U., Rumbiak, R.E.Y. 2019. Pembuatan Pestisida Nabati Untuk Mengendalikan Hama Dan Penyakit Pada Tanaman Sayuran Di Distrik Siepkosi Kabupaten Jayawijaya. Jurnal Pengabdian Kepada Masyarakat. 25(3):135-143. https://doi.org/10.24114/jpkm.v25i3.14806

Wihardjaka, A. 2018. Penerapan Model Pertanian Ramah Lingkungan sebagai Jaminan Perbaikan Kuantitas dan Kualitas Hasil Tanaman Pangan. Pangan. 27(2):155-164. https://doi.org/10.33964/jp.v27i2.376

Winarso, B. 2013. Kebijakan Pengembangan Komoditas Tanaman Pangan dalam Mendukung Program Master Plan Percepatan dan Perluasan Pembangunan Ekonomi Indonesia (MP3EI) Studi Kasus di Propinsi Gorontalo. Jurnal Penelitian Pertanian Terapan. 13(2):85-102. https://doi.org/10.25181/jppt.v13i2.171 